\title{
The Value-Driven Strategy Models in Improving Higher Education Institutions' Performance
}

\author{
Pupung Purnamasari ${ }^{1, *}$ Ratih Hurriyati ${ }^{2,}$ Disman $^{3,}$ Lili Adi Wibowo ${ }^{4}$ \\ ${ }^{1}$ Universitas Pendidikan Indonesia \\ ${ }^{2}$ Universitas Pendidikan Indonesia \\ ${ }^{3}$ Universitas Pendidikan Indonesia \\ ${ }^{4}$ Universitas Pendidikan Indonesia \\ *Corresponding author.Email: pupungjurnal@gmail.com
}

\begin{abstract}
Since the advancement of higher education is inextricably linked to the passing of time, each college should focus on adapting to the evolving times of the modern age while continuing to improve their results. This study measures the effect of the value-driven strategy model in improving tertiary institution performances in West Java, Indonesia. A quantitative method was utilized as a research design involving 167 universities in West Java Province as the samples. The data analysis referred to the Structural Equation Model (SEM) to test the value-driven strategy on college performance. The results of the study showed that the performance of tertiary institutions was mainly influenced by the level of Value-driven strategy.
\end{abstract}

Keywords: Value-Driven Strategy, Performance.

\section{INTRODUCTION}

The educational sector performance appraisal plays a critical role in a country's growth and development [1]. It establishes a set of performance management tools to help tertiary institutions meet their educational objectives and expectations while also increasing their competitiveness in a global setting [2]. Furthermore, higher education has evolved into a competitive market as a result of changes in a 21 st century society that is increasingly global, digital, and diverse [3]. In line with this, technological advancements and improvements in global conditions, referred to as industrial revolution 4.0 which affect changes in a more digital society. It allows everyone to get connected to the internet anywhere, and focuses on simplicity, speed, and effectiveness. Such a development encourages every college to concern on adjusting the evolved times without leaving aside to improve performance.

A study done by reference [4] describes the general strategies developed by universities in with some stakeholders. The great diversity of performance through collaborative strategies can be seen from the variables of knowledge and innovation management which was R2 = 0.0552 . It means that $55.2 \%$ of the changes in the university performance were influenced by knowledge and innovation managements. Meanwhile, the great diversity of performance through competitive strategies was inferred by the number of the variables, which was $\mathrm{R} 2=0.775$. It indicates that $77.5 \%$ of the changes in the university performance was affected by the knowledge management [4].

It is supported by reference [5] who conducted a case study about higher education management performance from the perspectives of customer revealed that there were three indicators of customers perspectives, namely satisfaction, retention, and acquisition, with the score of $6 \%$ or $60 \%$ of the maximum weighting score in the Balanced Scorecard of $10 \%$. The performance was measured from the perspectives of learning and growth with four indicators, such as employee satisfaction, employee retention, employee productivity, and information systems capability with a score of $16.9 \%$ or $84.5 \%$ of the maximum score. The total score of the participant was $60 \%$ of the customer perspectives and $84.5 \%$ of the growth and learning perspectives. It indicates the good performances of the participant [5].

Some related studies about measurement and performance appraisal have been done previously, including the study on tertiary education performance with a financial approach. These studies highlighted the 
issues related performance appraisal that can be overcome through internal and external environmental analysis and operational strategies, innovation and technology, leadership development, value creation, value-based management and cooperation.

Regarding this, this study aimed to solve problems through analysis of external and internal environment and value-driven strategy through partnerships, since the universities in Indonesia have problems about the value given and lack of funding for different aspects required by college performance. Value-driven strategy is one of the strategies integrating some solutions to understand some important issues in new competition, including the industrial 4.0 era. The approach of this strategy will be further identified considering the conditions of implementing partnerships and assessing both external and internal environment.

As suggested by reference [6] page 31, strategic management is an art and science in formulating, implementing, and evaluating cross-functional decisions that enable organizations to achieve their goals. The strategic management process consists of three stages, namely formulation, implementing, and evaluation. Strategy evaluation is the final stage in strategic management includes reviewing external and internal factors as the basic strategy, measuring performance, and taking corrective action. Evaluation is necessary to prepare the better future.

One of the activities of strategic management is measuring performance as an activity of assessment strategy. In higher education institutions, a re-evaluation of the generation of students, technological innovation, budget constraints and other economic factors acts as major components [7]. In addition, increased competition between higher education institutions in terms of attracting and maintaining students enable education managers to reconsider their strategies aimed at identifying elements and indicators of competitive advantage [7].

The variables of this study are Value-Driven Strategy (X) with external and internal environment as the dimensions, the performance of higher education (Y) with a moderator partnership $(Z)$. Value-driven strategy is the organization's instruction to develop a set of strategic "core values" and to implement an implementation plan to achieve higher conformity of core values at every level in the organization [8]. Higher education performance is a picture of the level of achievement of the implementation of an activity / program. Policies in realizing the goals, objectives, mission and vision of tertiary institutions are very strict and complex [9]. According to Muhammad Jafar Hafsah, the Partnership is a business strategy carried out by two or more parties within a certain period of time to be achieved together with the principle of mutual benefit and mutual fostering. Because it is a business strategy, the success of a partnership is determined by the existence of compliance among partners in carrying out business ethics [10].

\section{METHODS}

The approach used in this research is the Management Strategy approach in an effort to improve college performance. The method used is quantitative. As for the object of research as the dependent variable, namely college performance (Y) and Value-Driven Strategy with the dimensions of the external and internal environment as independent variables $(\mathrm{X})$. Th e unit of analysis used as respondents in this study is the University in West Java Province, Indonesia. The sample in this study were 226 universities in West Java Province. The data analysis technique used to test the effect of value-driven strategy on college performance is the Structural Equation Model (SEM).

\section{RESULTS AND DISCUSSION}

Test the suitability of the Structural Equation model produces a Chi-Square value of $100.507<$ Chi-Squares tabel ie 106.3948, and a P-value of $0.061>0.05$ indicates a fit model. RMSEA value of $0.058(\leq 0.08)$ means the model is fit with the data. Furthermore, the CFI match index is 0.974 , and GFI is 0.934 so it indicates the model fit with the data.

Structural model analysis is related to the evaluation of parameters that show a causal relationship or the effect of one latent variable on another latent variable. The following is a picture of the standardized loading factor estimation parameters as follows based on fig. 1 .

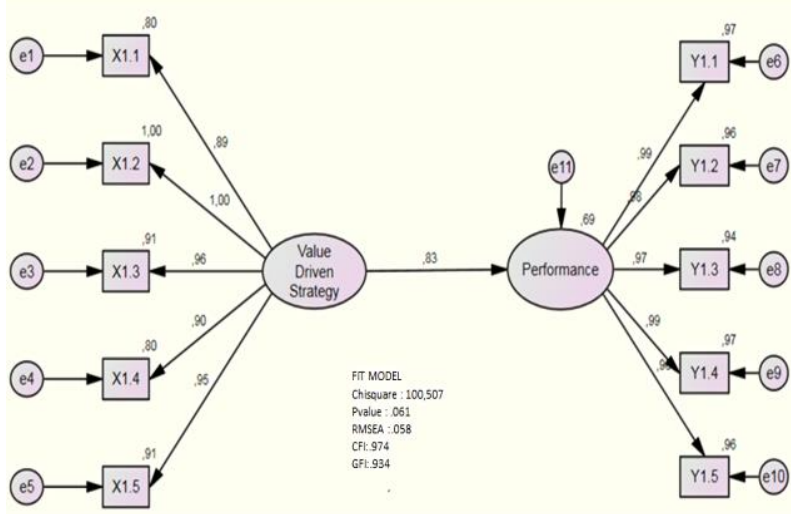

Figure 1 Structural model in the overall structural equation model

Based on the picture above, the structural model parameter estimation results are presented in the following table 1 . 
Table 1. Summary of Estimated Results of Structural Model Parameters

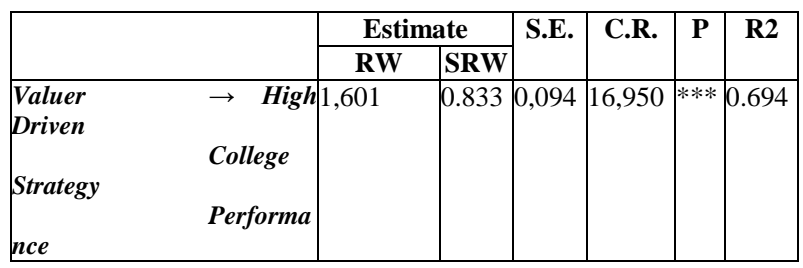

The table above shows the high and low performance of higher education is positively influenced by the high and low value driven strategy. This can be assessed from the path coefficient value of 0.833 (SRW>0) then Ho is rejected and $\mathrm{Ha}$ is accepted, meaning that there is a positive influence between value driven strategy on college performance. The magnitude of the influence of the external environment on the value driven strategy of 0.694 or equal to $(0.6942 \times 100 \%)=69.4 \%$ of the high and low variations that occur in college performance can be explained by the value driven strategy. The structural equation estimation for the value driven strategy model is:

Higher Education Performance $=0.833$ Value Driven

Strategy $+0.333 \mathrm{e} ; \mathrm{P} 2=0.694$

The Value-Driven Strategy Model in Figure 1 shows that the performance of tertiary institutions in the province of West Java is influenced by the level of the Value Driven Strategy. Value-driven strategies are organizational instructions to develop a set of strategic "core values" and to implement an implementation plan for conformance higher than core values at every level of the organization [8]. Internal factors include: organizational, technological, financial, and Human Resoirce while internal factors are government, IT and Industry. So far, previous research has only examined how to improve company performance as a measurement of company performance. Research on Value-Driven Strategy as one of the strategies for creating performance in tertiary institutions.

Reference [11] was stated developing a Value-Driven Mission Statement with the Results of the module not only developing mission statements that are driven by values (assignments), but also empowering students with reflection strategies and basic tools for class cases and future leadership and management decisions.

Based on the research that has been discussed above the strategy of providing added value to universities, the value given must be more than the sacrifice that has been done. Competitor conditions, what value competitors give to customers, what technology competitors use. Characteristics that characterize the market driven strategy is firstly making the market as an orientation (Becoming market orientation). At this stage universities must be able to make products, deliver products and deliver values based on what is needed and what the market wants so that customer satisfaction can be achieved. Second characteristics is determining distinctive capabilities where companies must know and analyze the company's special abilities, after knowing and analyzing what special abilities they have, the company must determine the capabilities that are truly unique from competitors. Third characteristic is matching customer values and distinctive capabilities where Higher Education must match specific abilities that have been determined with the value what is desired by the customer. After obtaining suitable abilities, universities must be able to integrate these capabilities so that they can convey values that can be accepted by the customer. Fourth characteristic is achieving superior performance. At this stage we must be able to maintain the company's performance that has been well received by the customer, must remain superior to competitors and be adaptive to existing changes.

\section{CONCLUSIONS}

Based on the results of the study it can be concluded that in improving the performance of tertiary institutions in West Java, Indonesia needs a value driven strategy. The influence of Value Driven Strategy on higher education performance is already high. Value-driven strategies provide strategic logic for pulling together and integrating a large number of strategy paradigms and models offered to understand the most important issues in the new competition companies facing. Value-driven management can be seen as a social form of organizational control that complements the organizational control system traditional.

\section{REFERENCES}

[1] S. K. Jauhar, M. Pant, and R. Dutt, "Performance measurement of an indian higher education institute: a sustainable educational supply chain management perspective," Int. J. Syst. Assur. Eng. Manag., 2018, doi: 10.1007/s13198-016-0505-4.

[2] S. H. Chen, C. C. Yang, and J. Y. Shiau, "The application of balanced scorecard in the performance evaluation of higher education," TQM Mag., 2006, doi: 10.1108/09544780610647892.

[3] F. Pucciarelli and A. Kaplan, "Competition and strategy in higher education: managing complexity and uncertainty," Bus. Horiz., 2016, doi: 10.1016/j.bushor.2016.01.003.

[4] D. Budiastuti, "Kondisi manajemen pengetahuan perguruan tinggi swasta di dki jakarta," Binus Bus. Rev., 2013, doi: 10.21512/bbr.v4i1.1058.

[5] N. Qomariah, "Kinerja manajemen perguruan tinggi ditinjau dari perspektif pelanggan dan 
perspektif pembelajaran dan pertumbuhan ( Studi Kasus Pada Universitas Muhammadiyah Jember )," J. Akunt. Investasi, 2013.

[6] F. R. David and F. R. David, Strategic management: concepts and cases (fifteenth). United States: Pearson, 2015.

[7] Y. Stukalina, "Strategic management of higher education institutions," Manag. Organ. Syst. Res., 2014, doi: 10.7220/mosr.1392.1142.2014.70.6.

[8] T. Järvensivu, "Values-driven management in strategic networks : a case study of the influence of organizational values on cooperation.," 2006.

[9] M. M. Kotob and M. Ali Abadi, "The influence of differentiated instruction on academic achievement of students in mixed ability classrooms," Int. Linguist. Res., 2018, doi: 10.30560/ilr.v2n2p8.

[10] S. Indris and I. Primiana, "Internal and external environment analysis on the performance of small and medium industries smes in indonesia," Int. J. Sci. Technol. Res., 2015.

[11] V. A. Paulins, J. L. Hillery, and A. Sturgill, "Ethical business leadership: a simulation to develop valuedriven mission statements," Dev. Bus. Simul. Exp. Learn., 2016.

[12]Z. Arifin, Penelitian pendidikan: metode dan paradigma baru. Bandung: PT Remaja Rosda Karya, 2006.

[13] S. Arikunto, Prosedur penelitian suatu pendekatan praktek. Jakarta: Rineka Cipta, 2011.

[14] S.A rikunto, Prosedur penelitian suatu pendekatan praktek. Jakarta: Rineka Cipta, 2006.

[15]H. K. Dipojono, Universitas kelas dunia dan pemeringkatan universitas dunia, 1-7, 2006.

[16]R. Garber, Academic-corporate engagement: strategic and organizational best practices, 22(1), 1-14, 2017.

[17]K. Giusepponi and E. Tavoletti, "Vision and mission statements in italian universities : results of an empirical investigation on strategic orientation," https://doi.org/10.1007/s13132-015-0343-7, 2015.

[18]L. Ginsburg and N. Miller, Value-driven management, 2007.

[19] Hair, et al, Multivariate data analysis (6th ed.). New Jersey: Pearson Education, 2006.

[20]A. Paulins and A. Sturgill, Developing value driven mission Statements, 43, 317-321, 2016. 